\title{
Process Validation Protocol of Granules for Oral Administration
}

\author{
Sayef Shahriad Ripon ${ }^{1 *}$, Akhlaque Hasan Khan ${ }^{2}$, Samir Kumar Bakshi ${ }^{1}$, Tareq ${ }^{2}$, Kshitish Chandra Das ${ }^{1}$ and $M o s t a f a$ \\ Kamal Parvez ${ }^{2}$ \\ ${ }^{1}$ Mundipharma (Bangladesh) Pvt. Ltd, Mirzapur, Gazipur, Bangladesh \\ ${ }^{2}$ Genvio Pharma Limited, Bagan, Trishal, Mymensingh, Bangladesh
}

*Corresponding Author: Sayef Shahriad Ripon, Mundipharma (Bangladesh) Pvt. Ltd, Mirzapur, Gazipur, Bangladesh.

Received: November 05, 2019; Published: November 19, 2019

DOI: $10.31080 /$ ASPS.2019.03.0441

\begin{abstract}
To ensure that the pharmaceutical product is being produced with its consistent quality standard, process validation is a very effective tool. It establishes documented evidence to ensure a high degree of assurance that specific process will consistently produce a product meeting its predetermined specifications and quality requirements. Process validation is a cGMP requirement for finished products and to standardize the method used in establishing process validation studies, a process validation protocol is developed. Based on the protocol, once the process validation is done, a complete process validation report will be prepared which will aid in preparing a complete BMR and BPR for manufacturing and packaging of pharmaceutical products.
\end{abstract}

Keywords: Process Validation; Protocol; CGMP; BMR; BPR

\section{Introduction}

Process (Prospective) validation aims to gain full understanding of the manufacturing process on the production equipment expected to be routinely used. This is achieved by establishing parameters to be used to operate within a state of control. Once the validation of process is completed, a Batch Manufacturing Record (BMR) to be finalized to use in routine manufacturing. Any variation mode to this BMR should be made in accordance with change control procedure [1-5].

\section{Purpose}

The purpose of this protocol is to cover the process validation activities for the manufacturing of Granules for oral administration. Based on the Technology Transfer set Parameters, three consecutive successful batches will be manufactured and finalized the critical process parameters for the batch manufacturing.

\section{Scope}

This protocol is applicable to validate Granules for Oral Administration under specified manufacturing conditions. This protocol shall define the responsibilities of personnel involved, equipment used, raw material details, critical process parameters, in-process control, quality attributes, acceptance criteria, change control, documentation to be carried out during Process Validation study of Granules for Oral Administration.

Product details

Product Name, Generic Name, Dosage Form, Product Category, Product Description, Label Claim, Packaging, Batch No., Mfg. Date, Exp. Date, Batch Size, Shelf Life, Product Code No.

\section{Documentation}

Check the following documents: Process Validation Protocol, Master Formulation Card, Master Packaging Card, Batch Manufacturing Record, Batch Packaging Record, Standard Test Specification, Standard Testing Procedure and Process Validation Report etc.

\section{Validation team}

The process validation team is comprised of at least one representative from all concern departments i.e. QA, QC, Production, Warehouse and Maintenance Department and the validation activity will be led by Head of Validation or Head of QA. 
Responsibilities

\begin{tabular}{|c|c|c|}
\hline Department & Activities & Responsibility \\
\hline \multirow{6}{*}{$\begin{array}{l}\text { Quality } \\
\text { Assurance }\end{array}$} & To prepare validation protocol. & \multirow[t]{5}{*}{ Officer } \\
\hline & $\begin{array}{l}\text { To ensure the activities to be } \\
\text { followed as per the approved } \\
\text { protocol. }\end{array}$ & \\
\hline & $\begin{array}{l}\text { To withdraw the samples as } \\
\text { per sampling program. }\end{array}$ & \\
\hline & $\begin{array}{l}\text { To organize the training and } \\
\text { impart the training before } \\
\text { validation. }\end{array}$ & \\
\hline & $\begin{array}{l}\text { To co-ordinate the validation } \\
\text { activity. }\end{array}$ & \\
\hline & To approve the protocol. & Head, QA \\
\hline \multirow{2}{*}{$\begin{array}{l}\text { Quality } \\
\text { Control }\end{array}$} & To analyze the samples. & Analyst \\
\hline & To check the results & Head, QC \\
\hline \multirow[t]{4}{*}{ Production } & To review validation protocol. & \multirow{2}{*}{$\begin{array}{l}\text { Officer/Head, } \\
\text { PR }\end{array}$} \\
\hline & $\begin{array}{l}\text { To ensure performance of } \\
\text { activities as per protocol. }\end{array}$ & \\
\hline & To organize the activity. & \multirow[t]{2}{*}{ Head, PR } \\
\hline & To review the report. & \\
\hline Maintenance & To provide required services. & $\begin{array}{l}\text { Officer/Head, } \\
\text { MN }\end{array}$ \\
\hline Head, Plant & To authorized the protocol. & GM, Plant \\
\hline
\end{tabular}

Table 1

\section{Training}

The training on the protocol shall be imparted to all the personnel involved in the process validation activity (QA, QC, Production, Warehouse and Maintenance).

\section{Validation methodology}

- The validation will be performed on three consecutive batches of the same batch size following the established manufacturing process described in this validation protocol.

- The validation study will be carried out at extreme and optimum values within the accepted ranges of critical process parameters. All critical parameters shall be monitored and documented for reviewed.

- In process sampling will be carried out as per the sampling plan given in this protocol.
- $\quad$ Finished product sampling and testing will be carried out as per respective established procedure.

- During execution of the validation batches, Batch Manufacturing Record (BMR) and Batch Packaging Record (BPR) will be completed as per respective procedure.

\section{List of equipments}

Make a list of all the machine, equipment and instrument to be used during process validation activity of respective products. The list should include; equipment ID, Model Number, Manufacturer, Capacity, Material of Construction, Qualification status and the respective Operating SOP

\section{Location of validation activity}

Mention the name and address of the place where the process validation activity will be done.

\section{Master manufacturing formula}

Master Manufacturing formula includes Name of the ingredients with their compendia name, Quantity/sachet (mg), Quantity/ Batch $(\mathrm{Kg})$ and the category and use of each ingredient.

Identification of critical process variables parameter Probable causes that may affect final products

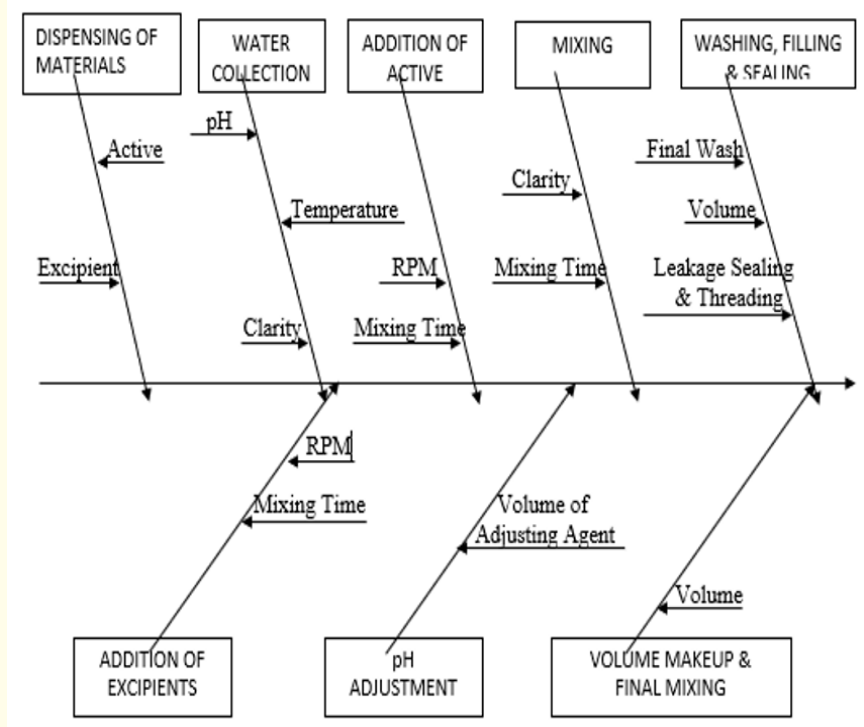

Figure 1: Probable Causes. 
Critical process parameter

\begin{tabular}{|c|c|}
\hline \multirow[t]{6}{*}{ Stage: Manufacturing } & Process Parameter \\
\hline & Manufacturing Area Temperature \\
\hline & Manufacturing Area RH \\
\hline & Ampere Load \\
\hline & Total Drying Time \\
\hline & Moisture Content (By KFT) \\
\hline \multirow[t]{4}{*}{ Stage: Blending } & Mixing Time \\
\hline & Bulk Density (Tapped) \\
\hline & Sieve Analysis (Fines) \\
\hline & Weight of the Granules \\
\hline \multirow{12}{*}{$\begin{array}{l}\text { Stage: Filling and } \\
\text { Sealing }\end{array}$} & Filling Area Temperature \\
\hline & Filling Area RH \\
\hline & Sealing Temperature (Bottom Sealer) \\
\hline & Sealing Temperature (Vertical Sealer) \\
\hline & Sealing Temperature (Top Sealer) \\
\hline & Machine Speed \\
\hline & Auger Speed \\
\hline & Auger Count \\
\hline & Leak Test \\
\hline & Quality of Batch Printing \\
\hline & Packaging Area temperature \\
\hline & Packaging Area RH \\
\hline
\end{tabular}

Table 2
Sampling, test parameters and acceptance criteria Sampling plan and sampling location

Wear nose mask and surgical hand gloves before Sampling. Take out $75 \mathrm{~g}$ sample as shown in the table from Top, Middle and Bottom of the blender, in a clean polyethylene bag. Label the samples with Product Name, Batch No., Stage, Area, Time and Date. Send the samples to QC for analysis. Ensure that no further mixing is done in QC.

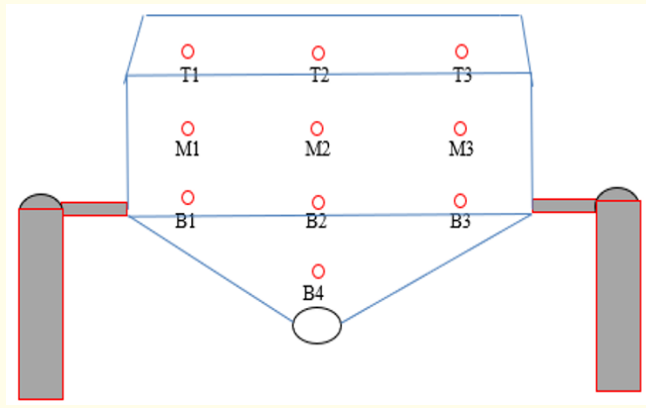

o Sampling Points

T1: Top 1, T2: Top 2, T3: Top 3, M1: Middle 1, M2: Middle 2, M3: Middle 3, B1: Bottom 1, B2: Bottom 2, B3: Bottom 3, B4: Bottom 4 Figure 2: Octagonal Blender.

\begin{tabular}{|c|c|c|c|c|c|}
\hline \multicolumn{6}{|c|}{ Stage: Granulatation } \\
\hline \multicolumn{6}{|c|}{ Drying } \\
\hline Sl. & $\begin{array}{l}\text { Sampling } \\
\text { Location }\end{array}$ & Sampling Points & Frequency & $\begin{array}{l}\text { Sampled } \\
\text { Quantity }\end{array}$ & $\begin{array}{l}\text { Test To Be } \\
\text { Carried Out }\end{array}$ \\
\hline 1. & FBD Bowl & $\begin{array}{c}\text { After drying from } \\
\text { Top, Middle and } \\
\text { Bottom layer of FBD } \\
\text { Bowl. }\end{array}$ & $\begin{array}{l}\text { One sample from each Tray (Top, Middle and } \\
\text { Bottom) }\end{array}$ & $1 \mathrm{~g} \mathrm{X} 6$ & Moisture Content \\
\hline \multicolumn{6}{|c|}{ Drying } \\
\hline 1. & Tray Dryer & $\begin{array}{l}\text { After drying from } \\
\text { Top, Middle and Bot- } \\
\text { tom layers. }\end{array}$ & $\begin{array}{l}\text { One sample from each Tray (Top two, Middle } \\
\text { two and Bottom Two). }\end{array}$ & $1 \mathrm{~g} \mathrm{X} 6$ & Moisture Content \\
\hline \multicolumn{6}{|c|}{ Blending } \\
\hline \multirow[t]{2}{*}{1.} & $\begin{array}{l}\text { Octagonal } \\
\text { Blender }\end{array}$ & $\begin{array}{c}\text { After drying from } \\
\text { Top (T1, T2 and T3), } \\
\text { Middle (M1, M2 and } \\
\text { M3) and Bottom } \\
\text { Trays (B1, B2, B3 and } \\
\text { B4). }\end{array}$ & $\begin{array}{l}10 \text { samples each after } 05 \text { minutes, } 08, \text { minutes } \\
\text { and } 10 \text { minutes }\end{array}$ & $\begin{array}{l}1 \mathrm{~g} \mathrm{X} 10 \\
\text { (Triplicate) }\end{array}$ & Assay of individual sample. \\
\hline & & Composite Sample. & After completion of mixing. & $60 \mathrm{~g}$ & $\begin{array}{l}\text { Bulk analysis as per } \\
\text { specifications, bulk density } \\
\text { and sieve analysis. }\end{array}$ \\
\hline & & 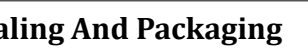 & & & \\
\hline
\end{tabular}




\begin{tabular}{|c|c|c|c|c|c|}
\hline \multirow[t]{4}{*}{1.} & \multirow{4}{*}{$\begin{array}{l}\text { Sachet } \\
\text { Filling and } \\
\text { Sealing } \\
\text { Machine }\end{array}$} & \multirow{4}{*}{$\begin{array}{l}\text { During sachet filling } \\
\text { and sealing operation } \\
\text { (Auger speed 900- } \\
1000 \text { rpm, Auger } \\
\text { count 2000-2500 } \\
\text { No.) }\end{array}$} & $\begin{array}{l}\text { At Machine Speed } 60 \text { Sachet/Min and Sealing } \\
\text { Temp. (Bottom) } 135^{\circ} \mathrm{C} \text {, Sealing Temp. (Vertical) } \\
150^{\circ} \mathrm{C} \text {, Sealing Temp. (Top) } 175^{\circ} \mathrm{C} \text {. }\end{array}$ & $\begin{array}{c}5 \\
15 \\
\text { sachets }\end{array}$ & \multirow[t]{3}{*}{$\begin{array}{l}\text { Appearance, Physical Veri- } \\
\text { fication, Leak test, Average } \\
\text { Fill and Fill Variation. }\end{array}$} \\
\hline & & & $\begin{array}{l}\text { At Machine Speed } 70 \text { Sachet/Min and Sealing } \\
\text { Temp. (Bottom) } 135^{\circ} \mathrm{C} \text {, Sealing Temp. (Vertical) } \\
150^{\circ} \mathrm{C} \text {, Sealing Temp. (Top) } 175^{\circ} \mathrm{C} .\end{array}$ & $\begin{array}{c}15 \\
\text { sachets }\end{array}$ & \\
\hline & & & $\begin{array}{l}\text { At Machine Speed } 80 \text { Sachet/Min and Sealing } \\
\text { Temp. (Bottom) } 135^{\circ} \mathrm{C} \text {, Sealing Temp. (Vertical) } \\
150^{\circ} \mathrm{C} \text {, Sealing Temp. (Top) } 175^{\circ} \mathrm{C} .\end{array}$ & $\begin{array}{c}15 \\
\text { sachets }\end{array}$ & \\
\hline & & & $\begin{array}{c}\text { Initial, Middle and End at Optimum speed and } \\
\text { sealing Temperature and Full, Half and Low } \\
\text { Hopper. }\end{array}$ & $\begin{array}{c}15 \text { sachets } \\
\text { each }\end{array}$ & $\begin{array}{l}\text { Appearance, Average Mass, } \\
\text { Uniformity of Mass, Quality } \\
\text { of Batch Printing, Leak Test } \\
\text { and Assay. }\end{array}$ \\
\hline 2. & $\begin{array}{l}\text { Packing } \\
\text { Room }\end{array}$ & From Packing Belt & As per SOP & $\begin{array}{c}21 \\
\text { sachets }\end{array}$ & $\begin{array}{l}\text { Complete analysis as per } \\
\text { specification. }\end{array}$ \\
\hline
\end{tabular}

Table 3

\section{Specifications}

Bulk specification

Bulk specification should include description, identification, solubility in water, $\mathrm{pH}$, moisture content and assay of granules.

\section{Finished product specification}

Bulk specification should include description, identification, average mass, uniformity of mass, solubility in water, $\mathrm{pH}$, moisture content, assay and microbial limit test of granules.

Operation

Dispensing details

\begin{tabular}{|l|c|}
\hline \multicolumn{1}{|c|}{ Operation/Parameter } & Std. Specification \\
\hline Room Cleaning & Should be clean \\
\hline Equipment Cleaning & Should be clean \\
\hline Utensils Cleaning & Should be clean \\
\hline Equipment Calibration & Should be calibrated \\
\hline Temperature & Not more than $25^{\circ} \mathrm{C}$ \\
\hline Humidity & Not more than $60 \%$ \\
\hline Material Dispensing & Should complies to BOM \\
\hline
\end{tabular}

Table 4

\section{Bill of materials (Bom)}

All the ingredients should be dispensed as per approved Bill of Materials. Care should be taken to ensure that right materials are being dispensed in right quantity.
Sifting details

\begin{tabular}{|l|c|}
\hline \multicolumn{1}{|c|}{ Operation/Parameter } & Std. Specification \\
\hline Room Cleaning & Should be clean \\
\hline Equipment Cleaning & Should be clean \\
\hline Equipment Calibration & Should be calibrated \\
\hline Sifting Area Temperature & Not more than $25^{\circ} \mathrm{C}$ \\
\hline Sifting Area Humidity & Not more than $50 \%$ \\
\hline Frequency of Recording & Initial and every one hour interval \\
\hline Sieve Used & Sieve Size and Sieve Integrity \\
\hline
\end{tabular}

Table 5

Granulation details

\begin{tabular}{|l|c|}
\hline \multicolumn{2}{|c|}{ Pre-check For Granulation and Conditioning } \\
\hline \multicolumn{1}{|c|}{ Operation/Parameter } & Std. Specification \\
\hline Room Cleaning & Should be clean \\
\hline Equipment Cleaning & Should be clean \\
\hline Equipment Calibration & Should be calibrated \\
\hline Area Temperature & Not more than $25^{\circ} \mathrm{C}$ \\
\hline Area Humidity & Not more than $60 \%$ \\
\hline Frequency of Recording & $\begin{array}{c}\text { Initial and every one hour } \\
\text { interval }\end{array}$ \\
\hline
\end{tabular}

Table 6 
Stepwise batch manufacturing operation

\begin{tabular}{|c|c|c|c|}
\hline Sl. No. & Step Instruction & \multicolumn{2}{|c|}{$\begin{array}{l}\text { Std. Specification/ } \\
\text { Parameter }\end{array}$} \\
\hline \multicolumn{4}{|c|}{ Stage I: Granulation } \\
\hline \multirow[t]{3}{*}{ Step-1 } & \multirow[t]{3}{*}{ Sieving } & \multicolumn{2}{|l|}{ Sieve Used } \\
\hline & & \multirow{2}{*}{ Sieve Integrity } & Before \\
\hline & & & After \\
\hline Step-2 & Solvent & \multicolumn{2}{|l|}{ PW Quantity } \\
\hline \multirow[t]{2}{*}{ Step-3 } & \multirow[t]{2}{*}{ Dry mixing } & \multicolumn{2}{|l|}{ Impeller Speed } \\
\hline & & \multicolumn{2}{|l|}{ Mixing Time } \\
\hline \multirow[t]{5}{*}{ Step-4 } & \multirow[t]{5}{*}{ Wet Mixing } & \multicolumn{2}{|l|}{ Impeller Speed } \\
\hline & & \multicolumn{2}{|l|}{ Chopper Speed } \\
\hline & & \multicolumn{2}{|l|}{ Solvent Quantity } \\
\hline & & \multicolumn{2}{|l|}{ Mixing Time } \\
\hline & & \multicolumn{2}{|l|}{ Amperage } \\
\hline \multirow[t]{3}{*}{ Step-5 } & \multirow[t]{3}{*}{ Drying in FBD } & \multicolumn{2}{|c|}{ Inlet Temperature } \\
\hline & & \multicolumn{2}{|c|}{ Outlet Temperature } \\
\hline & & \multicolumn{2}{|c|}{ Total Drying Time } \\
\hline \multirow[t]{3}{*}{ Step-6 } & \multirow[t]{3}{*}{ Sizing } & \multicolumn{2}{|l|}{ Screen Used } \\
\hline & & \multirow{2}{*}{ Sieve Integrity } & Before \\
\hline & & & After \\
\hline Step-7 & $\begin{array}{l}\text { Send the sample to QC for } \\
\text { determination of moisture } \\
\text { content. }\end{array}$ & Moisture Conte & \\
\hline \multicolumn{4}{|c|}{ Stage II: Blending } \\
\hline & During the granules with & Blender Speed & \\
\hline Step-8 & Blender Machine & Blending Time & \\
\hline Step-9 & $\begin{array}{l}\text { Send the sample to QC for } \\
\text { determination of moisture } \\
\text { content. }\end{array}$ & $\begin{array}{l}\text { Assay and blenc } \\
\text { uniformity }\end{array}$ & \\
\hline Stage I & : Packaging (Sachet Filling & Sealing and Pac & raging) \\
\hline $\begin{array}{l}\text { Step- } \\
10\end{array}$ & $\begin{array}{l}\text { Packaging (Sachet Filling, } \\
\text { Sealing and Packaging) at }\end{array}$ & $\begin{array}{l}\text { Filling Area } \\
\text { Temperature }\end{array}$ & \\
\hline & Lower speed, higher speed & Filling Area RH & \\
\hline & $\begin{array}{l}\text { and optimum speed with } \\
\text { full, medium and low hop- }\end{array}$ & Average Net We & ight \\
\hline & per & Machine Speed & \\
\hline & & Auger Speed & \\
\hline & & Auger Count & \\
\hline & & $\begin{array}{l}\text { Sachet Sealing } \\
\text { Temperature [B }\end{array}$ & ottom] \\
\hline & & $\begin{array}{l}\text { Sachet Sealing } \\
\text { Temperature [V }\end{array}$ & ertical] \\
\hline & & $\begin{array}{l}\text { Sachet Sealing } \\
\text { Temperature [T }\end{array}$ & \\
\hline & & Leak Test & \\
\hline & & Quality Of Batcl & Printing \\
\hline & & $\begin{array}{l}\text { Packing Area } \\
\text { Temperature }\end{array}$ & \\
\hline & & Packing Area RI & \\
\hline
\end{tabular}

Table 7

\section{Yield reconciliation}

Calculate the yield as per BMR and BPR and find out the maximum and minimum range.

\begin{tabular}{|l|l|}
\hline \multicolumn{1}{|c|}{ Operation / Parameters } & Purpose \\
\hline After Blending & For Information only \\
\hline After Filling & For Information only \\
\hline
\end{tabular}

Table 8

Stability

Carry out the normal room temperature and accelerated temperature stability studies as per the stability protocol. This stability shall be concurrent stability.

\section{Summary}

Summary report and conclusion shall be prepared and approved based on the acceptance criteria and the data collected during Process Validation studies and all the results shall be verified against acceptance criteria.

\section{Discrepancy and corrective action}

Report any discrepancy observed in the process or test result beyond the standard specification and mention what corrective and preventive action is taken against the discrepancy.

\section{Approval}

Based on the results reported and summary in the validation reports, approve the process validation report as preliminary and final approval. Approval section should include; prepared by, checked by, verified by, approved by and authorized by signature with date.

\section{Conclusion}

If validation is not done, product quality may vary from batch to batch of manufacturing. To avoid this limitation, process validation activity poses a significant role in establishing documented evidence to ensure consistent quality product meeting its controlled specification. The outcome of this paper is to focus the importance and stepwise procedure for conducting process validation through an approved validation protocol.

\section{Bibliography}

1. EU Guidelines for Good Manufacturing Practice for Medicinal Products for Human and Veterinary Use; Ares 4 (2015).

2. Comparative Framework Between New Product and Legacy Product Process Validation-Mark Mitchell, Pharmatech Associates, Inc. 
3. FDA Guidance for Industry; Process Validation: General Principles and Practices; Revision-1 (2011).

4. General guidance on hold-time studies, WHO Technical Report Series Annex4 (2015): 992.

5. Guide to Good Manufacturing Practice for Medicinal Products Part II, (C) Pic/S (2018).

Volume 3 Issue 12 December 2019

(C) All rights are reserved by Sayef Shahriad Ripon., et al. 